\title{
Trace metal ions release from fixed orthodontic appliances and DNA damage in oral mucosa cells by in vivo studies: A literature review
}

\author{
Patrycja Downarowicz, A-F, Marcin Mikulewicz ${ }^{2, A, E, F}$ \\ ${ }^{1}$ Department of Facial Abnormalities, Wroclaw Medical University, Poland \\ ${ }^{2}$ Department of Maxillofacial Orthopedics and Orthodontics, Wroclaw Medical University, Poland \\ A - research concept and design; $\mathrm{B}$ - collection and/or assembly of data; $\mathrm{C}$ - data analysis and interpretation; \\ $D$ - writing the article; $E$ - critical revision of the article; $F$ - final approval of article
}

Address for correspondence

Patrycja Downarowicz

E-mail: p.downarowicz@gmail.com

Funding sources

None declared

Conflict of interest

None declared

Received on June 9, 2016

Revised on July 19, 2016

Accepted on October 7, 2016

\begin{abstract}
An overview of professional literature referring to the release of metal ions from fixed orthodontic appliances and their influence on oral mucosa in conditions of in vivo are presented, along with a detailed analysis of the exposure of the cells of cheek mucosa epithelium to metal ions. Electronic databases (PubMed, Elsevier, Ebsco) were searched with no language restrictions. The relevant orthodontic journals and reference lists were checked for all eligible studies. A total of 38 scientific articles were retrieved in the initial search. However, only 7 articles met the inclusion criteria. Statistically significant differences in the levels of the amount of nickel ions, cobalt ions and chromium ions were observed in cells of cheek mucosa. The most biocompatible material used in the production of fixed orthodontic appliances is titanium, and the least biocompatible material is steel, which releases the largest amount of nickel and chromium. Metal ions are released from fixed orthodontic appliances only in the first phase of treatment. It is recommended to conduct further, long-term research on a larger number of patients to define the influence of using fixed orthodontic appliances and biological effect they might have on tissues.
\end{abstract}

Key words: atomic absorption spectrophotometry, cells of cheek mucosa, chromium ions, nickel ions, orthodontic treatment

DOI

10.17219/acem/65726

\section{Copyright}

Copyright by Author(s)

This is an article distributed under the terms of the

Creative Commons Attribution Non-Commercial License

(http://creativecommons.org/licenses/by-nc-nd/4.0/) 
Contemporary orthodontics (orthodontic trade companies and orthodontists alike), take utmost care to apply materials that would be close to $100 \%$ biocompatible with the tissues of the patients' oral cavity. Elements which constitute the orthodontic fixed appliances (bands, braces, wires) are manufactured from metal alloys which undergo corrosion in the environment of the oral cavity. ${ }^{1,2}$ As a result of this process, metal ions (mostly nickel, chromium, cobalt and iron) are released into the human body. ${ }^{3,4}$ These metals are well known to be cytotoxic, mutagenic and allergic agents. ${ }^{5,6}$ Biocompatibility studies (in vivo, in vitro and usage tests) aim to evaluate the effects of exposure to the metal ions released from orthodontic appliances to the human body. ${ }^{7-9}$ In order to achieve this, different biomarkers of exposure, such as saliva, blood, urine, hair, nails and oral mucosa cells, are used, with each of them having their advantages and disadvantages. ${ }^{10,11}$ Blood, as an invasive biomarker, is more difficult to collect; moreover, blood and saliva have a window of detection, of approximately 36-72 h. Hair is a well-known biomarker, easy to collect and store in keeping with the established laboratory procedures, which can provide information about chronic exposure. ${ }^{12-15}$ Oral mucosa cells are a non-invasive biomarker that is easy to collect. The advantage of this biomarker is that fixed orthodontic appliances are in direct contact with the cells, which can supply information about ion concentration. Thus, oral mucosa cells are the first tissue where a localized corrosion effect takes place.

The aim of this systematic literature review was to present the concentration of metal ions in the cells of the cheek mucosa of orthodontic patients and their influence on DNA damage in in vivo tests.

\section{Material and methods}

\section{Search strategy}

The following electronic databases were searched by 2 independent researchers (without language restriction): MEDLINE via PubMed (from 1960 to January 2015), Elsevier (from 1980 to January 2015), Ebsco (from 1980 to January 2015). A manual search of the following journals was performed: American Journal of Orthodontics and Dentofacial Orthopedics, Angle Orthodontics, European Journal of Orthodontics (all from 1980 to January 2015). The following key words were applied in this study: 1 . fixed orthodontic appliances; $2 \mathrm{a}$. release of metal ions; $2 \mathrm{~b}$. nickel; $3 \mathrm{a}$. in vivo; $3 \mathrm{~b}$. cells of cheek mucosa; 4 . 1 and (2a or $2 \mathrm{~b}) ; 5.1$ and (3a or $3 \mathrm{~b}) ; 6.1$ and (2a or $2 \mathrm{~b}$ ) and (3a or $3 \mathrm{~b}$ ); 7. 1 and ( $2 \mathrm{a}$ or $2 \mathrm{~b})$ and ( $3 \mathrm{a}$ or $3 \mathrm{~b})$ not in vitro. The combination of key words and the results of looking through the databases are presented in Table 1.

All the articles that satisfied the criteria for being included in this paper review have been qualified on the basis of the contents of their abstracts.
Table 1. Key words which became the sought-after phrases in PubMed resources (search strategies)

\begin{tabular}{|c|c|c|}
\hline No. & Word/phrase & Result \\
\hline 1. & fixed orthodontic appliance & 2247 \\
\hline 2a. & releasing metal ions & 62007 \\
\hline 2b. & nickel & 34033 \\
\hline $3 a$. & in vivo & 656627 \\
\hline $3 b$. & 1 and (2a or 2b) & 7947 \\
\hline 4. & 1 and (3a or 3b) & 6 \\
\hline 5. & 1 and (2a or 2b) and (3a or 3b) & 3 \\
\hline 6. & 1 and (2a or 2b) and (3a or 3b) not in vitro & 3 \\
\hline 7. &
\end{tabular}

The following inclusion criteria were used:

1. Type of studies: clinical in vivo studies conducted on patients before, during and after orthodontic treatment with fixed orthodontic appliances.

2. Patients aged between 12 and 35 .

3. All participants have permanent dentition, no amalgam fillings or metal restorations, no previous orthodontic treatment, no palatal or lingual appliances welded to the bands, and no extra-oral auxiliary orthodontic appliances. None of the subjects had oral diseases, systemic diseases, illnesses related to genetic damage, diabetes, and allergies to costume jewelry, watches, or any other sources of nickel or chromium. They were not treated with antibiotics or steroids during the study period. None of the subjects were addicted to cigarettes, alcohol or drugs. They did not use alcohol-based mouthwashes.

4. Comparisons: These included the concentration of metal ions in particular groups in the cells of the cheek mucosa before, during and after orthodontic treatment. An assessment of the amount of damaged cells of the cheek mucosa before, during and after orthodontic therapy was carried out as well.

\section{Quality assessment and control of bias}

The quality assessment and control of bias were performed using the application of the methodological checklist for prognostic studies developed by the National Institute for Health and Clinical Excellence of the United Kingdom (Fig. 2) ${ }^{16}$ During the ranking of selected studies, it was verified that they had very similar scores, which meant: up to 5 "yes" = high; up to 3 "yes" = moderate; 2 or fewer "yes" = low.

\section{Data extraction}

The following data was extracted from the selected articles and tabulated by the 2 authors: (1) source, 
(2) material and methods, (3) methods of collecting material, (4) metal ions, (5) concentration of metal ions.

\section{Results}

During the initial search, 38 articles were deemed potentially relevant to the review; 21 were rejected, including duplicates. Then, the titles and abstracts of 17 articles were assessed, of which 10 were excluded. Only 7 of them fulfilled the inclusion criteria. The primary reasons for rejection are shown in the PRISMA flow diagram (Fig. 1). The accepted articles are presented in Table 2 . The material examined contained only the cells of the cheek mucosa epithelium, which was obtained from patients before, during and after orthodontic therapy. The concentrations of metal ions that were sought contained nickel (all articles), chromium (3 out of 5 articles), cobalt ( 4 out of 5 articles), iron ( 1 out of 5 articles), molybdenum ( 1 out of 5 articles) and titanium ( 1 out of 5 articles). In the studies mentioned above, the following analytical techniques were applied: ICP-MS (3 papers) and AAS with graphite furnace (2 papers, Table 3 ). The nonparametric test (Kolmogorov-Smirnov) in statistical analysis turns out to have been more popular (3 papers).

Other tests included the parametric Student's t-test (2 papers), nonparametric Wilcoxon test (1 paper), Fisher's exact test (1 paper), Friedman test (1 paper), Levene's test ( 1 paper) and Tukey's test ( 1 paper). Nonparametric tests were used more frequently than parametric tests. In Table 3 we present the concentrations of metal ions in the cells of the cheek mucosa. Tables 4 and 5 present research in which the authors define the number of damaged cells of the cheek mucosa.

The information includes materials and methodology as well as conclusions. The research is presented in chronological order.
Faccioni et al. evaluated nickel and cobalt levels in oral mucosa cells. ${ }^{17}$ The fixed orthodontic appliances were in the upper and lower jaw (20 brackets, $4-8$ bands each). The metal ions were released during the first 4 or 5 months of orthodontic therapy. Epithelial cells of the buccal mucosa were collected by gently brushing the internal part of the right and left cheek with an interdental brush. The cells were immediately prepared for the cell viability and the comet assay. Nickel and cobalt cellular content was quantified by inductively coupled plasma mass spectrometry (ICP-MS). The authors reported an increase in the cobalt and nickel level in oral mucosa cells in the group treated orthodontically, 2.8-fold and 3.4-fold higher, respectively. The potential genotoxic effects, evaluated by alkaline comet assay, indicated that both metals (nickel and cobalt) induced DNA damage. It was found that the presence of nickel and cobalt released from orthodontic appliances induced DNA damage and reduced the cellular viability of mucosa cells.

Amini et al.evaluated nickel, chromium and cobalt levels in oral mucosa cells. ${ }^{18}$ For the patients in the experimental group, the average period since the insertion of the appliance to the time of sample collection was 16 months. Mucosa samples were collected by gently brushing the internal part of the right and left buccal mucosa with an interdental brush. The concentration of nickel, chromium and cobalt ions was quantified using atomic absorption spectrophotometry with a graphite furnace. The authors did not find statistically significant differences in chromium $(p=0.09)$ and cobalt $(p=0.10)$ levels between the experimental and control samples $(\mathrm{p}<0.05)$. Unlike chromium and cobalt, the average levels of nickel in the experimental and control patient groups were significantly higher (21.74 and $12.26 \mathrm{ng} / \mathrm{mL}$, respectively).

Hafez et al. evaluated the nickel and cobalt levels in oral mucosa cells. ${ }^{19}$ The cells were collected before treatment

Table 2. Research which has been included in the review

\begin{tabular}{|c|c|c|c|c|c|c|}
\hline \multirow[b]{2}{*}{ Source } & \multicolumn{2}{|c|}{ Material and methods } & \multirow{2}{*}{$\begin{array}{l}\text { Method of } \\
\text { collecting material }\end{array}$} & \multirow[b]{2}{*}{ Metal ions } & \multirow{2}{*}{$\begin{array}{l}\text { Methods of } \\
\text { measurement }\end{array}$} & \multirow[b]{2}{*}{ Statistics } \\
\hline & $\begin{array}{l}\text { test group } \\
\text { (age) }\end{array}$ & $\begin{array}{l}\text { control group } \\
\text { (age) }\end{array}$ & & & & \\
\hline $\begin{array}{l}\text { Faccioni et al. } \\
\qquad(2003)\end{array}$ & $55(12-35)$ & $30(12-33)$ & interdental brush & $\mathrm{Co}, \mathrm{Ni}$ & ICP-MS & Student's t-test \\
\hline $\begin{array}{l}\text { Amini et al. } \\
\text { (2008) }\end{array}$ & $30(18.2)$ & 30 & interdental brush & $\mathrm{Co}, \mathrm{Cr}, \mathrm{Ni}$ & $\begin{array}{l}\text { AAS with a } \\
\text { graphite furnace }\end{array}$ & Student's t-test \\
\hline $\begin{array}{l}\text { Angelieri et al. } \\
\qquad(2011)\end{array}$ & $23(18.5 \pm 7)$ & - & $\begin{array}{l}\text { moist wooden } \\
\text { spatula }\end{array}$ & metal ions & not given & Friedman test \\
\hline $\begin{array}{l}\text { Natarajan et al. } \\
\qquad(2011)\end{array}$ & $20(14-24)$ & 20 & metal spatula & $\mathrm{Ni}, \mathrm{Cr}$ & ICP-MS & $\begin{array}{l}\text { Kolmogorov-Smirnov test, } \\
\text { Mann-Whitney } U \text { test }\end{array}$ \\
\hline $\begin{array}{l}\text { Fernandez-Minano et al. } \\
\qquad(2011)\end{array}$ & $\begin{array}{c}5 \times 3 \text { groups } \\
(12-16)\end{array}$ & - & interdental brush & $\begin{array}{l}\mathrm{Ti}, \mathrm{Cr}, \mathrm{Mn}, \mathrm{Co} \\
\mathrm{Ni}, \mathrm{Mo}, \mathrm{Fe}\end{array}$ & ICP-MS & $\begin{array}{l}\text { Kolmogorov-Smirnov test, } \\
\text { Levene test, Tukey test }\end{array}$ \\
\hline $\begin{array}{l}\text { Hafez et al. } \\
\text { (2011) }\end{array}$ & $28(20.2 \pm 4.4)$ & 18 & $\begin{array}{l}\text { wooden tongue } \\
\text { depressor }\end{array}$ & $\mathrm{Ni}, \mathrm{Co}$ & $\begin{array}{l}\text { AAS with } \\
\text { a graphite furnace }\end{array}$ & Wilcoxon test Fisher test \\
\hline $\begin{array}{l}\text { Heravi et al. } \\
\text { (2013) }\end{array}$ & $25(16.3 \pm 3.6)$ & - & metal spatula & metal ions & not given & Kolmogorov-Smirnov test \\
\hline
\end{tabular}


Table 3. The concentration of metal ions in particular groups in the cells of cheek mucosa $\mathrm{ng} / \mathrm{mL}$

\begin{tabular}{|c|c|c|c|c|c|c|c|c|}
\hline \multirow{3}{*}{ Source } & \multicolumn{8}{|c|}{ Concentration of metal ions } \\
\hline & \multicolumn{2}{|c|}{$\mathrm{Ni}$} & \multicolumn{2}{|c|}{$\mathrm{Cr}$} & \multicolumn{2}{|c|}{ Co } & \multicolumn{2}{|c|}{$\mathrm{Fe}$} \\
\hline & test & control & test & control & test & control & test & control \\
\hline Faccioni et al. (2003) & $2.521^{1}$ & $\begin{array}{c}0.725 \\
\pm 0.629^{1}\end{array}$ & - & - & $0.568^{1}$ & $\begin{array}{c}0.202 \\
\pm 0.091^{1}\end{array}$ & - & - \\
\hline Amini et al. (2008) & $21.74 \pm 11.41^{1}$ & $12.26 \pm 12.9^{1}$ & $4.24 \pm 1.82$ & $3.46 \pm 1.65$ & $0.84 \pm 1.06$ & $0.44 \pm 0.74$ & - & - \\
\hline \multirow{4}{*}{$\begin{array}{l}\text { Natarajan et al. } \\
\text { (2011) }\end{array}$} & \multicolumn{8}{|c|}{ level of metal ions before debonding } \\
\hline & $4.09 \pm 3.20$ & $3.86 \pm 2.17$ & $3.63 \pm 3.24$ & $2.71 \pm 1.73$ & - & - & - & - \\
\hline & \multicolumn{8}{|c|}{ level of metal ions 30 days after debonding } \\
\hline & $3.84 \pm 1.94$ & $3.48 \pm 1.55$ & $2.94 \pm 1.97$ & $2.26 \pm 1.73$ & - & - & - & - \\
\hline \multirow{6}{*}{$\begin{array}{l}\text { Fernandez Minano et al. } \\
\text { (2011) }\end{array}$} & \multicolumn{8}{|c|}{ stainless steel alloy } \\
\hline & $0.04 \pm 0.07$ & $3.44 \pm 2.79$ & 0.00 & 0.00 & 0.00 & 0.00 & $2.01 \pm 0.46$ & $1.95 \pm 1.29$ \\
\hline & \multicolumn{8}{|c|}{ titanium alloy } \\
\hline & 0.00 & $3.44 \pm 2.79$ & 0.00 & 0.00 & 0.00 & 0.00 & $1.24 \pm 0.79$ & $1.95 \pm 1.29$ \\
\hline & \multicolumn{8}{|c|}{ nickel-free alloy } \\
\hline & 0.00 & $3.44 \pm 2.79$ & $0.34 \pm 0.29$ & 0.00 & 0.00 & 0.00 & $5.36 \pm 2.44$ & $1.95 \pm 1.29$ \\
\hline \multirow{4}{*}{$\begin{array}{l}\text { Hafez et al. } \\
\text { (2011) }\end{array}$} & \multicolumn{8}{|c|}{ level of metal ions after 3 months fixed appliance placement } \\
\hline & 0.68 & 0.52 & $0.41^{1}$ & $0.31^{1}$ & - & - & - & - \\
\hline & \multicolumn{8}{|c|}{ level of metal ions after 6 months fixed appliance placement } \\
\hline & 0.78 & 0.52 & $0.78^{1}$ & $0.31^{1}$ & - & - & - & - \\
\hline
\end{tabular}

${ }^{1}$ Statistically essential differences between groups; ${ }^{2}$ The authors do not give information about the level of metal ions in the tests, but they define the amount of damaged cells in cheek mucosa.

Table 4. The assessment of the amount of damaged cells in cheek mucosa

\begin{tabular}{|c|c|c|c|c|}
\hline \multirow{2}{*}{ Source } & \multicolumn{3}{|c|}{ Micronucleated cells } & \multirow[b]{2}{*}{30 days after debonding } \\
\hline & before & during & after orthodontic therapy & \\
\hline Angelieri et al. (2011) & $0.04 \%$ & $0.07 \%$ & $0.05 \%$ & - \\
\hline Hafez at al. (2011) & $8.1 \%$ & $6.4 \%$ & $4.5 \%$ & - \\
\hline Natarajan et al. (2011) & - & - & $259 \pm 233$ & $48 \pm 49$ \\
\hline \multirow{6}{*}{$\begin{array}{l}\text { Fernandez Minano et al. } \\
\text { (2011) }\end{array}$} & & \multicolumn{2}{|c|}{30 days after titanium alloy placement } & \\
\hline & $25.87 \pm 3.41$ & \multicolumn{2}{|c|}{$42.6 \pm 8.93$} & - \\
\hline & & \multicolumn{2}{|c|}{30 days after stainless steel alloy placement } & \\
\hline & $69.35 \pm 11.68$ & \multicolumn{2}{|c|}{$68.41 \pm 26.63$} & - \\
\hline & & \multicolumn{2}{|c|}{30 days after nickel-free alloy placement } & \\
\hline & $69.35 \pm 11.68$ & \multicolumn{2}{|c|}{$68.41 \pm 26.63$} & - \\
\hline Heravi et. al. (2013) & $10.6 \pm 5.7$ per 1000 cells & - & $9.2 \pm 6.37$ per 1000 cells & - \\
\hline
\end{tabular}


Table 5. Cytotoxicity and frequency of buccal cells with comet and apoptotic cells in controls $(n=30)$ and patients $(n=55)$ with fixed orthodontic appliances for $2-4$ years (Faccioni et al., 2003)

\begin{tabular}{|l|c|c|c|}
\multicolumn{1}{|c|}{ Parameters } & Controls & Patients & p-value \\
\hline $\begin{array}{l}\text { Comets } \\
\text { (100 cells per sample) }\end{array}$ & $11.43 \pm 6.58$ & $17.62 \pm 10.08$ & 0.0047 \\
\hline $\begin{array}{l}\text { Apoptosis } \\
\text { (100 cells per sample) }\end{array}$ & $1.00 \pm 2.26$ & $3.15 \pm 4.93$ & 0.021 \\
$\begin{array}{l}\text { Viability } \\
(\%)\end{array}$ & $73.43 \pm 12.29$ & $50.40 \pm 13.55$ & 0.0001 \\
\hline
\end{tabular}

and 3-6 months after the placement of the appliance. Epithelial cells of the buccal mucosa were collected by gently brushing the internal part of the right and left cheeks with a wooden tongue depressor. The cells were immediately prepared for the cell viability and the comet assay. The nickel and cobalt cellular content determinations were carried out with the use of atomic absorption spectrometry with a graphite furnace. The authors reported an increase in nickel from 0.52 to 0.68 and $0.78 \mathrm{ng} / \mathrm{mL}$ and chromium from 0.31 to 0.41 and $0.78 \mathrm{ng} / \mathrm{mL}$ at 3 and 6 months, respectively. The potential genotoxic effect, evaluated by alkaline comet assay, indicated that both metals induced DNA damage and decreased cellular viability. Compared to the control group, these changes were not evident at 6 months, possibly indicating a tolerance by or repair of the cells and the DNA.

Fig. 1. PRISMA flow diagram

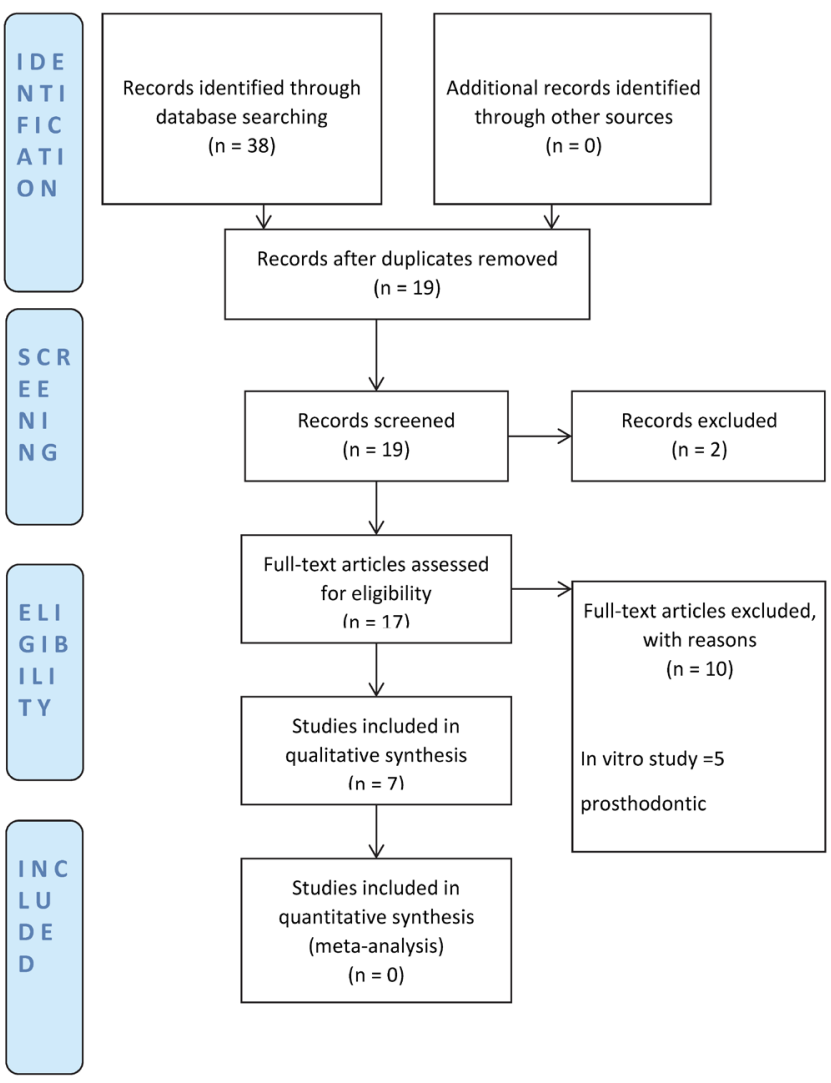

Natarajan et al. also investigated the levels of nickel and chromium in oral mucosa cells. ${ }^{20}$ Oral mucosa smears were collected 2 times: at debonding and 30 days after debonding. Mucosa samples were collected by gently brushing the internal part of the right and left buccal mucosa with a metal spatula. The concentration of nickel and chromium ions was quantified using inductively coupled plasma-mass spectrometry. The authors did not find statistically significant differences in chromium and nickel levels between the experimental and control samples. The potential genotoxic effect, evaluated by $\mathrm{MN}$ assay, indicated that both metals induced localized genotoxic effects, but did not have a damaging influence on the DNA after fixed appliances had been removed. The nickel and chromium concentrations in the oral mucosal cells were not significantly different from the norm, although the chromium concentration was higher in the experimental group.

Fernandez-Minano et al. evaluated metallic ions (titanium, chromium, manganese, cobalt, nickel, molybdenum and iron) in oral mucosa cells. ${ }^{21}$ There was no control group. The authors evaluated metal ions released from 3 alloys (stainless steel, $\mathrm{n}=5$; titanium, $\mathrm{n}=5$; nickel-free, $\mathrm{n}=5$ ). Samples from the oral mucosa were taken before treatment and 30 days later. Mucosa samples were collected by gently brushing the internal side of the right and left buccal mucosa with an interdental brush. The cells were immediately prepared for the cell viability and the comet assay. The concentrations of titanium, chromium, manganese, cobalt, nickel, molybdenum and iron were quantified using inductively coupled plasma mass spectrometry (ICP-MS). The authors confirmed that among the most biocompatible materials were titanium, then nickel-free and stainless steel, which released the highest amount of ions. Both stainless steel and nickel-free alloys induced more DNA damage in the oral mucosa cells than the titanium alloy.

Angelieri et al. estimated DNA damage (micronucleus) and cellular death in exfoliated buccal mucosa cells from adults after fixed orthodontic therapy. ${ }^{22}$ There was no separate control group. The cells were collected by scraping the left and right cheek mucosa with a moist wooden spatula. The cells were then prepared for the cell viability and the micronucleus assay. Before the beginning of orthodontic therapy, the average frequency of micronucleated cells was $0.04 \%$. The conclusion was that the concentration of ions in oral mucosa cells did not increase significantly as a result of orthodontic therapy (before, during and after orthodontic therapy, $\mathrm{p}>0.05$ ). The authors reported that orthodontic therapy might not be a factor that induces chromosomal damage, nor was it able to promote cytotoxicity.

Heravi et al. also investigated the level of toxic metal ions from orthodontic alloys. ${ }^{23}$ There was no separate control group. Mucosa samples were collected by gently brushing the internal side of the right and left buccal mucosa with a metal spatula in a sweeping motion. 
Table 6. Methodological checklist for prognostic studies developed by the National Institute for Health and Clinical Excellence from the United Kingdom used to perform the quality assessment and control of bias

\begin{tabular}{|c|c|c|c|c|c|c|}
\hline & $\begin{array}{l}\text { Study sample } \\
\text { represents the } \\
\text { population of } \\
\text { interest with } \\
\text { regard to key } \\
\text { charakteristics, } \\
\text { sufficient to limit } \\
\text { potential bias }\end{array}$ & $\begin{array}{l}\text { Loss to follow-up } \\
\text { is unrelated to key } \\
\text { characteristics } \\
\text { sufficient to limit } \\
\text { potential bias }\end{array}$ & $\begin{array}{l}\text { Prognostic } \\
\text { factor of interest } \\
\text { is adequately } \\
\text { measured, } \\
\text { sufficient to limit } \\
\text { potential bias }\end{array}$ & $\begin{array}{c}\text { Outcome of } \\
\text { interest is } \\
\text { adequately } \\
\text { measured, } \\
\text { sufficient to limit } \\
\text { bias }\end{array}$ & \begin{tabular}{|} 
Important potential \\
confounders are \\
appropriately \\
accounted for, \\
limiting potential \\
bias with respect \\
to the prognostic \\
factor of interest
\end{tabular} & $\begin{array}{l}\text { Statistical analysis } \\
\text { is appropriate for } \\
\text { the design of the } \\
\text { study, limiting } \\
\text { potential for the } \\
\text { presentation of } \\
\text { invalid results }\end{array}$ \\
\hline $\begin{array}{l}\text { Faccioni et al. } \\
\text { (2003) }\end{array}$ & yes & yes & yes & yes & yes & unclear \\
\hline $\begin{array}{l}\text { Amini et al. } \\
\text { (2008) }\end{array}$ & yes & yes & yes & yes & yes & unclear \\
\hline $\begin{array}{l}\text { Angelieri et al. } \\
\text { (2011) }\end{array}$ & unclear & yes & yes & yes & yes & yes \\
\hline $\begin{array}{l}\text { Natarajan et al. } \\
\text { (2011) }\end{array}$ & yes & yes & yes & yes & yes & yes \\
\hline $\begin{array}{l}\text { Fernandez-Minano } \\
\text { (2011) }\end{array}$ & yes & yes & yes & yes & yes & yes \\
\hline $\begin{array}{l}\text { Hafez et al. } \\
\text { (2011) }\end{array}$ & yes & yes & yes & yes & yes & yes \\
\hline $\begin{array}{l}\text { Heravi et al. } \\
\text { (2013) }\end{array}$ & yes & yes & yes & yes & yes & yes \\
\hline
\end{tabular}

The oral mucosa cells were collected just before appliance placement and 9 months later. No significant difference was found in the $\mathrm{MN}$ count before $(10.6 \pm 5.7$ per 1000 cells) and 9 months after therapy $(9.2 \pm 6.37$ per 1000 cells, $p=0.336)$. It was found that the presence of metal ions released from orthodontic appliances did not induce DNA damage and did not reduce the cellular viability of mucosa cells.

\section{Discussion}

Typical steel for the production of the parts of fixed orthodontic appliances, like brackets and bands, contains $8-12 \%$ nickel. ${ }^{24}$ Nickel-titanium arches contain about $47-50 \%$ nickel. ${ }^{25,26}$ In their in vitro research, Sfondrini et al. proved that the highest amount of chromium is released from new steel brackets $(0.52-1.083 \mu \mathrm{g} / \mathrm{g})$, but less from recycled brackets $(0.27-0.38 \mu \mathrm{g} / \mathrm{g}){ }^{27}$

Some symptoms of allergy to nickel may appear in the oral cavity in patients treated with fixed orthodontic appliances. The symptoms include inflammation of gums and tongue, gingival hypertrophy, erythema multiforme, exfoliation of the lip epithelium and metallic aftertaste in the mouth. ${ }^{28,29}$

Both nickel and chromium may cause infections of the skin and asthma as well as genotoxic and cytotoxic effects in cells and tissues of the body. 29,30

Additional factors such as the local environment, place of work, working conditions, diet, exaggerated slimming, regular use of alcohol and tobacco as well as individual sensitivity may additionally strengthen the role of nickel and chromium in the etiology of serious general diseases.
That is why it seems important to define the number of metal ions that are released daily from fixed orthodontic appliances in both in vitro and in vivo tests. ${ }^{31-33}$ The concentrations of metal ions in the cells of the cheek mucosa and the conclusions from the research are different in the analyzed reports. This may result from using differing methods of preparing the material for testing and from applying different analytical methods in the research. Faccioni et al. and Amini et al.report a double or triple increase in the level of nickel and cobalt ions in the cells of cheek mucosa epithelium. ${ }^{17,18}$ Statistically significant differences were observed for cobalt $(\mathrm{Co})^{17}$, nickel $(\mathrm{Ni})^{17,18}$ and chromium $(\mathrm{Cr})^{19}$. In another study, the differences between cobalt and chromium were not statistically significant, although the p-level was low (0.09 and $0.10) .{ }^{18}$ In the Fernandez-Minano study, after 30 days of contact with fixed orthodontic appliances, the cheek mucosa cells of the patients increased their concentrations of titanium and manganese. ${ }^{21}$ For the patients wearing titanium orthodontic appliances, the manganese content increased and wearers of nickel-free apparatus showed increased concentrations of chromium and iron. Some researchers have failed to find differences in chromium ion concentration. ${ }^{18}$ Natarajan et al. have observed that the nickel and chromium ion concentrations in the oral mucosa cells were not significantly different from the norm, although the chromium concentration was higher in the test group. That study has shown that the maximum release of metals occurs within the first 4-5 months. ${ }^{20}$

The different concentrations of metal ions released can be explained by the different experimental methodologies and materials, such as the proportions of the elements in the appliances, the manufacturing of the orthodontic parts 
and sometimes also the materials (NiTi wires, $\mathrm{SS}$ wires, etc.) and analytical techniques with different lower detection limits. Faccioni et al. used ICP-MS and reported nickel ions of $2.521 \mathrm{ng} / \mathrm{mL}$ in the test group and $0.725 \mathrm{ng} / \mathrm{mL}$ in the control group, while Amini et al. used AAS with a graphite furnace and reported nickel ions of $21.74 \mathrm{ng} / \mathrm{ml}$ in the test group and $12.26 \mathrm{ng} / \mathrm{mL}$ in the control group. ${ }^{17,18}$ Also, the studies were carried out between the years 2003 (Faccioni et al.) and 2013 (Heravi et al). The sensitivity of the applied analytical techniques has improved significantly in recent years. Additionally, in 3 of the studies, no control group was used. ${ }^{21-23}$ Finally, ion release from fixed orthodontic devices in vivo is affected by various factors, such as saliva composition, $\mathrm{pH}$, dietary habits, and microflora.

The assessment of the number of damaged cells of the cheek mucosa was different in the presented studies. Faccioni et al. presented 3 forms damaging the DNA structure (comets, apoptosis and viability), whereas other authors presented one in different units. ${ }^{17,19-23}$ The results presented by Angelieri et al. and Heravi et al. showed that the micronucleus frequencies were not significantly different before, during and after orthodontic treatment, and are in contrast with those of Natarajan et al., who found a significantly higher MN count in the test group at the day of debonding as compared to the control group without appliances. ${ }^{20,22,23} \mathrm{Hafez}$ et al. ${ }^{19}$ found that the cytotoxicity and genotoxicity of orthodontic appliances remained in the mouth for 6 months. According to Natarajan et al. and Hafez et al. fixed orthodontic appliances emit metal ions in sufficient quantities to induce a localized genotoxic effect, but these changes were not more evident after a longer time. ${ }^{19,20}$ Faccioni et al. have observed the genotoxic damage induced by orthodontic therapy in cheek mucosa cells as assessed by single-cell comet assay in vivo. ${ }^{17}$ Their studies showed an increase in the number of comets. This study proved that nickel and cobalt released from fixed orthodontic appliances can induce DNA damage in cheek mucosa cells.

The differences in the results shown in the analyzed articles might result from many causes. One of the most important factors seems to be the length of the time the patient was wearing the fixed appliance, as well as the time of collecting the cells of cheek mucosa epithelium. Another significant factor exerting an influence on the test results might be the method of measuring the damage in DNA (MN assay, comet assay and so on). The remaining differences may stem from a different number of patients in the test group and the control group, lack of control group or the age of the patients.

\section{Conclusions}

Stainless steel was the least biocompatible material used in the production of fixed orthodontic appliances since it released the largest amount of nickel and chro- mium. Titanium, therefore, should be the most preferable material in orthodontic treatment.

The metal ions are only released from fixed orthodontic appliances in the first phase of treatment.

It is recommended that further long-term research on a larger number of patients be conducted to define the influence of fixed orthodontic appliances and their possible biological effect on tissues.

\section{References}

1. House K, Sernetz F, Dymock D, Sandy JR, Ireland AJ. Corrosion of orthodontic appliances: Should we care? Am J Orthod Dentofacial Orthop. 2008;133:584-592.

2. Kusy RP. Types of corrosion in removable appliances: Annotated cases and preventative measures. Clin Orthod Res. 2000;3:230-239.

3. Maia L, Filho H, Ruellas A, Araujo M, Vaitsman D. Corrosion behavior of self-ligating and conventional metal brackets. Dental Press J Orthod. 2014;19:108-114.

4. Rafeeq R, Saleem A, Nissan L. lons release from fixed orthodontic appliance in two different mouthwashes. J Bagh Coll Dentistry. 2014:26:152-155.

5. Pillai A, Gangadharan A, Gangadharan J, Kumar N. Cytotoxic effects of the nickel release from the stainless steel brackets: An in vitro study. J Pharm Bioallied Sci. 2013;5:1-4.

6. Ahmed R, Aref M, Hassan R, Mohammed N. Cytotoxic effect of composite resin and amalgam filling materials on human labial and buccal epithelium. Nature and Science. 2010;10:48-53.

7. Kocadereli I, Atac A, Kale S, Ozer D. Salivary nickel and chromium in patients with fixed orthodontic appliances. Angle Orthod. 2000;70:431-434.

8. Okazaki Y, Gotoh E. Comparison of metal release from various metallic biomaterials in vitro. Biomaterials. 2005;26:11-21.

9. Huang $\mathrm{H}$, Chiu $\mathrm{Y}$, Lee $\mathrm{T}$, et al. Ion release from NiTi orthodontic wires in artificial saliva with various acidities. Biomaterials. 2003;24:3585-3592.

10. Petoumenou E, Arndt M, Keilig L, et al. Nickel concentration in the saliva of patients with nickel-titanium orthodontic appliances. Am J Orthod Dentofacial Orthop. 2009;135:59-65.

11. Agaoglu G, Arun T, Izgu B, Yarat A. Nickel and chromium levels in the saliva and serum of patients with fixed orthodontic appliances. Angle Orthod. 2001;71:375-379.

12. Kempson IM, Lombi E. Hair analysis as a biomonitor for toxicology, disease and health status. Chem Soc Rev. 2011:40:3915-3940.

13. Mikulewicz M, Wołowiec $P$, Loster B, Chojnacka K. Metal ions released from fixed orthodontic appliance affect hair mineral content. Biol Trace Elem Res. 2015;163:11-18.

14. Wołowiec P, Michalak I, Chojnacka K, Mikulewicz M. Hair analysis in health assessment. Clin Chin Acta. 2013;419:139-171.

15. Gil F, Hernandez AF, Marquez C, et al. Biomonitorization of cadmium, chromium, manganese, nickel and lead in whole blood, urine, axillary hair and saliva in an occupationally exposed population. Sci Total Environ. 2011;409:1172-1180.

16. Marquezan M, Osorio A, Sant'Anna E, Souza MM, Maia L. Does bone mineral density influence the primary stability of dental implants? A systematic review. Clin Oral Implants Res. 2012;23:767-774.

17. Faccioni F, Franceschetti P, Cerpelloni M, Fracasso ME. In vivo study on metal release from fixed orthodontic appliances and DNA damage in oral mucosa cells. Am J Orthod Dentofacial Orthop. 2003;124:687-694.

18. Amini F, Borzabadi Farahani A, Jafari A, Rabbani M. In vivo study of metal content of oral mucosa cells in patients with and without fixed orthodontic appliances. Orthod Craniofac Res. 2008;11:51-56.

19. Hafez HS, Selim EMN, Eid FHK, Tawfik WA, Al-Ashkar EA, Mostafa YA. Cytotoxicity, genotoxicity, and metal release in patients with fixed orthodontic appliances: A longitudinal in-vivo study. Am J Orthod Dentofacial Orthop. 2011;140:298-308.

20. Natarajan M, Padmanabhan S, Chitharanjan A, Narasimhan M. Evaluation of the genotoxic effects of fixed appliances on oral mucosal cells and the relationship to nickel and chromium concentrations: An in-vivo study. Am J Ortho Dentofacial Orthop. 2011;40:383-388. 
21. Fernandez-Minano E, Ortiz C, Vicente A, Calvo JL, Ortiz AJ. Metallic ion content and damage to the DNA in oral mucosa cells of children with fixed orthodontic appliances. Biometals. 2011;24:935-941.

22. Angelieri F, Carlin V, Martins R, Ribeiro A. Biomonitoring of mutagenicity and cytotoxicity in patients undergoing fixed orthodontic therapy. Am J Orthod Dentofacial Orthop. 2011;139:e399-e404.

23. Heravi F, Abbaszadegan MR, Merati M, Hasanzadeh N, Dadkhah E, Ahrari F. DNA damage in oral mucosa cells of patients with fixed orthodontic appliances. J Dent. 2013;10:494-500.

24. Huang TH, Yen CC, Kao CT. Comparison of ion release from new and recycled orthodontic brackets. Am J Orthod Dentofacial Orthop. 2001;120:68-75.

25. Eliades T, Athanasiou AE. In vivo aging of orthodontic alloys: Implications for corrosion potential, nickel release, and biocompatibility. Angle Orthod. 2002;72:222-237.

26. Kerosuo H, Moe G, Kleven $\mathrm{E}$. In vitro release of nickel and chromium from different types of simulated orthodontic appliances. Angle Orthod. 1995;65:111-116.

27. Sfondrini MF, Cacciafesta V, Maffia E, et al. Chromium release from new stainless steel, recycled and nickel free orthodontic brackets. Angle Orthod. 2009;79:361-367.

28. Lindsten R, Kurol J. Orthodontic appliances in relation to nickel hypersensitivity: A review. J Orofac Orthop. 1997;58:100-108.

29. Genelhu MCLS, Marigo M, Alves-Olivera LF, Malaquias LCC, Gomez RS. Characterization of nickel-induced allergic contact stomatitis associated with fixed orthodontic appliances. Am J Orthod Dentofacial Orthop. 2005;128:378-381.

30. Eliades T, Pratsisin H, Kletsas D, Eliades G, Macou M. Characterization and cytotoxicity of ions released from stainless steel and nickel-titanium orthodontic alloys. Am J Ortod Dentofacial Orthop. 2005;128:378-381.

31. Mikulewicz M, Chojnacka K, Wołowiec P. Release of metal ions from fixed orthodontic appliance: An in vitro study in continuous flow system. Angle Orthod. 2014;84:140-148.

32. Trombetta D, Mondello MR, Cimino F, Cristani M, Pergolizzi $S$, Saija A. Toxic effect of nickel in an in vitro model of human oral epithelium. Toxicology Letters. 2005;159:219-225.

33. Angelieri F, Marcondes JPC, de Almeida DC, Salvadori DMF, Ribeiro DA. Genotoxicity of corrosion eluates obtained from orthodontic brackets in vitro. Am J Orthod Dentofacial Orthop. 2011;139:504-509. 